subject to Jordan and Falk's Newer Knowledge of Bacteriology and Immunology in 1928, and to the Medical Research Council's A System of Bacteriology in 1930.

Having used an improved heated blood agar plate, better known as chocolate agar, for culturing gonococci McLeod then included a critical concentration of potassium tellurite, previously described by Conradi and Troch in 1912, in this medium for the selective growth of Corynebacterium diphtheriae. This combination of a much improved growth medium and an efficient selective agent made possible the recognition of two, and later three distinct colonial types of diphtheria bacilli. McLeod and his team soon realized that these three distinct colonial types were related to differential growth characters in nutrient broth and to type-specific polysaccharide and sugar fermentation reactions. From these observations McLeod's concept of these three biotypes being linked to three different degrees of clinical severity of the infection was born and he named these biotypes accordingly, i.e. gravis, mitis and intermedius.

The first paper by the Leeds team in 1931 triggered a flood of research effort by many bacteriologists in all parts of the world and kept the Leeds Department busy until the incidence of clinical diphtheria had declined so much that work came to a halt for lack of material and interest. Finally in 1950 McLeod validated his concept of the relation of the three main $C$. diphtheriae biotypes to clinical severity in an authoritative survey of reports on 25,000 cases from all corners of the globe, which was published in the Journal of Pathology and Bacteriology.

The main currents of McLeod's research activities were interspersed with papers on post-operative tetanus infection arising from soil dust in a surgical theatre, the prophylactic value of some antiseptics in experimental streptococcal wound infections, the carriage of Bord. pertussis in contacts of clinical cases, the differential laboratory diagnosis of $\mathrm{Cl}$. oedematiens and the factor in nutrient agar which inhibits the antibacterial action of sulphonamides.

After retirement McLeod, somewhat reluctantly, had a two-year period of research inactivity but then began investigations in an Edinburgh hospital and for the Scottish hospitals Endowments Research Trust into the causes, reservoirs of, and urinary tract infections caused by $P$ s. aeruginosa in paraplegics and was able to propose some measures of prevention. When the grant ceased he was given research hospitality in the Edinburgh Central Microbiological
Laboratories where he participated in a series of investigations, published in the British Medical Journal in 1967, that provided the foundation for quantitative cellülar and bacterial urine examination in newborns, infants and young children.

J. W. McLeod is survived by his second wife Joyce, a son and five daughters with whom all former associates share a great sense of loss.

K. Zinnemann

\section{J. A. Douglas}

Professor J. A. Douglas, D.Sc., Emeritus Professor of Geology and Palaeontology in the University of Oxford, died on 27 February 1978, at the age of 93 .

James Archibald Douglas was born at Ilkley, Yorkshire on 1 December 1884. $\mathrm{He}$ was educated at Haileybury and Keble College, Oxford which he entered in 1902 as Open Scholar in Zoology. He took a First Class Honours in Geology in 1905 and, with the award of the Burdett-Coutts University Scholarship, began research under the versatile professor, W. J. Sollas. Douglas's first work was on the changes of physical constants which take place in certain minerals and igneous rocks, on the passage from the crystalline to the glassy state and he soon became involved in Sollas's everchanging research interests which ranged from serial sectioning of fossil vertebrates to palaeoliths. $\mathrm{He}$ also began taking over at an early age an increasing amount of the undergraduate teaching. Nevertheless, Douglas spent several vacations in Ireland investigating the Carboniferous Limestone rocks of Co. Clare.

In 1910, he set out on a two years' geological exploration of the Andes in Peru and Bolivia at the suggestion and expense of W. E. Balston, a graduate of Oxford and generous benefactor of the University Museum. $\mathrm{He}$ finally completed this work after a return visit in 1929.

In August 1914, Douglas was commissioned and was on active service in France throughout the War, being wounded in 1915. On his return to France, he was seconded for mining duties and was responsible for the large mines at St Eloi, Messines Ridge in 1916, were he was wounded for the second time. In 1917 his corps of miners constructed the Grange Tunnel for the attack on Vimy Ridge.

When Douglas returned to Oxford in 1919, his chief was already seventy years of age, and although Sollas was to remain in control of the department for another seventeen years, he became increasingly remote and un- predictable, with interests that were almost exclusively anthropometric and archaeological. On Douglas almost exclusively, fell the task of coping with an overwhelming influx of ex-service students, not only honours men on shortened courses but engineering students and those destined for the Colonial forestry service. Everything had to be done on a very limited budget and constant improvisation, but Douglas's reward was in the friendships he then established with men destined to scatter to responsible posts throughout the world.

At this time, he began an association with the major petroleum companies and he was for thirty years Palaeontological Adviser on the Advisory Board of the Anglo-Iranian Oil Company, (British Petroleum Company). During this time most of the palaeontological material collected by the company's exploration staff was examined by him and the resulting reports and correlations incorporated his identifications.

In 1937, he succeeded to the Oxford chair and at once was able to carry out his long made plans for a revitalising of Oxford geology teaching and research. He obtained a substantial donation from Shell towards a new departmental building, and the plans were well-advanced in 1939. During the second War he was Town Defence Commander for Oxford.

The new Geology department was the first science building to be erected in Oxford after the war but already the post-war enlarged intake of students had been repeated and with it the need for improvisation and economy. Douglas had the satisfaction, however, of doing his last year of teaching in the new building. On retirement in 1949 , his break with the department he had served so long was almost complete, for he moved to Yarmouth, Isle of Wight. There he indulged his favourite pastime of sailing, racing his own yacht in competitions for many years, enjoying as he did perfect health till near the end of his long life.

Douglas was a joint secretary of the Geological Society of London with W. Campbell Smith from 1922-1929, and served on its Council for a total period of almost twenty years. His industry and achievements were not however of a type which readily attracts public awards and indeed he received few of these. He set far more importance on the satisfaction he received from the real affection and gratitude expressed by generations of former students most of whom moved into academic and industrial posts of responsibility across the world, and remained in touch with him as lifelong friends.

James M. Edmonds 